Utah State University

DigitalCommons@USU

1954

\title{
Additional Studies on the Effect of Field Applications of Insecticides on Honey Bees
}

\author{
F. V. Lieberman \\ George E. Bohart \\ Utah State University \\ G. F. Knowlton \\ William P. Nye \\ Utah State University
}

Follow this and additional works at: https://digitalcommons.usu.edu/piru_pubs

Part of the Entomology Commons

\section{Recommended Citation}

Lieberman, F. V.; Bohart, George E.; Knowlton, G. F.; and Nye, William P., "Additional Studies on the Effect of Field Applications of Insecticides on Honey Bees" (1954). All PIRU Publications. Paper 787.

https://digitalcommons.usu.edu/piru_pubs/787

This Article is brought to you for free and open access by the Pollinating Insects Research Unit at DigitalCommons@USU. It has been accepted for inclusion in All PIRU Publications by an authorized administrator of DigitalCommons@USU. For more information, please contact digitalcommons@usu.edu.

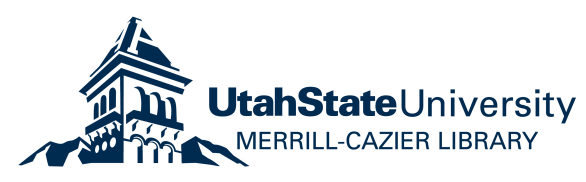




\title{
Additional Studies on the Effect of Field Applications of Insecticides on Honey Bees
}

\author{
F. V. Lieberman, G. E. Bohart, G. F. Knowlton, and W. P. Nye ${ }^{1}$
}

Choice of an insecticide treatment to be used on a legume seed crop in bloom should be determined by its hazard to bees as well as its economic effectiveness in controlling harmful insects. This is true not only because bees provide the cross-pollination essential to high yield of quality seed but also because most beekeepers still depend on a honey crop for their living.

In 1947 the staff of the U. S. Legume Seed Research Laboratory at Logan, Utah, initiated a study to ascertain which of the principal new organic insecticides could be applied to seed alfalfa in bloom without creating a serious threat to honey bees. This work has been continued each season with the exception of 1951. Most of the studies made prior to 1950 have been published (Todd et al. 1949, Knowlton et al. 1950). This paper is a report of 16 field tests conducted in 1950, 1952, and 1953.

Procedure.-To obtain results similar to those found in commercial practice, we have continued to conduct tests in the field rather than in laboratory or field cages. The procedures were basically the same as those previously described, but improvements made warrant a brief redescription.
Approximately 5 acres of 2-year-old alfalfa were provided each year by the Utah Agricultural Experiment Station in an area of little competing bloom that could be maintained reasonably free of extraneous honey bees and insecticide applications. About 1 week before the first test from 14 to 18 strong hives of bees were placed in a small plot adjacent to the alfalfa field. The plot was cleared of vegetation, smoothed, and marked off into an examination area within which would be found most of the adult bees dying at the hives.

Counts of bees working the field were made by recording the number instantaneously present within square-yard counting stations. These stations were marked off with a white string supported on corner lath stakes and were distributed systematically through the field, 68 being used in 1950 and 100 in the following years. Counts of dead bees in the field were made on 48 to 50 two-square-yard areas located systematically away from these stations. Since the alfalfa on these areas was sickled off to facilitate visual examination

1 The first two and last authors are connected with the Entomology Research Branch, Agricultural Research Service, U. S. Department of Agriculture, and Dr. Knowlton with the Utah Agricultural Experiment Station. 
of the field litter and soil surface, new areas were selected each day that dead bees were counted.

Dead bees were picked up around the hives between 6 and 7 A.M. Field visitors were counted between 10 and 11 A.M. and $1: 30$ and 2:30 P.M. The counts of dead bees in the field were made between 7 and 11 A.M., the fresh dead bees found being those that died while visiting flowers the previous day.

All the insecticides were applied during hours when few bees were visiting the field. Morning applications were made between 6 and 7 A.M., m.s.t. Evening applications were made after 7 P.M. A duster or sprayer mounted on a small farm tractor and connected with the power take-off was used. The duster was equipped with $12 \mathrm{~V}$-type nozzles 17 inches apart and connected by separate lines of flexible 2-inch tubing to a common fan chamber. The sprayer had a 30 -foot boom fitted with 18 nozzles discharging a flat, fan-shaped spray. In 1953 sprays were applied at the rate of 12 gallons per acre, in previous seasons at 8 gallons per acre. Tractor speed during all applications was approximately $5 \mathrm{~m} . \mathrm{p} . \mathrm{h}$. Pressure in the spray boom was maintained at 60 pounds per square inch.

The number of bees exposed to each treatment was estimated from counts at all stations on the day of application at the two periods of expected peak visitation. The higher of these totals multiplied by the proper factor for field size was then designated as the exposed population. The number of insecticide-killed bees dying at the hives was estimated by correcting the total number of bees picked up during the period of a test by a daily normal based on the dead bees found in the examination area for at least 2 days prior to treatment. The number of insecticide-killed bees dying in the field was estimated by multiplying the number of freshly killed poisoned bees found in all examination areas by the proper factor for field size. Bees were determined to be freshly dead and/or poisoned by noting deterioration of the digestive tract and the accumulation of fluids in the hind gut and comparing these changes with those occurring in check bees. Check bees were removed from a hive at the time of field treatment and placed in lots of five in small screen cages. One lot was killed by pinching, and several other lots were killed by placing the cages in the path of the application equipment and allowing them to be sprayed or dusted. All check bees were then placed in a representative spot in the field. One lot of sprayed bees was examined each day at the time dead bees found in the field were classified. Pinched bees were examined at this time only on the first day.

The total mortality resulting from an application is expressed as a percentage of the maximum number of bees visiting the field at any one time on the first day of exposure. This estimate is conservative in that it does not take into account bees leaving the field but not reaching the colonies or those returning to other colonies within flight range of the test field. On the other hand, the method of expressing field visitation probably exaggerates the true mortality, since it represents only the largest number on the field at one time and not the total of all bees visiting the field on the day of treatment.

Results.-Briefly summarized, tests conducted in the period 1947-49 (Todd et al. 1949) showed that (1) mortality of honey bees caused by field applications of the principal organic insecticides was confined to the field force and in most cases was essentially complete within 48 hours; (2) toxicity of toxaphene in seven tests at dosages providing effective control of several detrimental insects was always distinctly less than 10 per cent; and (3) except for methoxychlor, the insecticides tested were sufficiently toxic (more than 10 per cent) in at least one trial that further studies were considered necessary to learn whether there was a dosage safe for bees.

The objectives of the 1950 tests were to procure additional data on the effect of DDT and chlordane and again to compare spray and dust applications. Dosages selected for testing were those best suited for use in the control of alfalfa seed insects under Utah conditions, and applications of toxaphene were included. The results of these tests are presented in table 1.

The mortalities in these tests agree with those obtained in previous years. Toxaphene as a spray or dust killed few bees, DDT spray was markedly less toxic than DDT dust even at the low dosage of 
Table 1.-Mortality of honey bees caused by toxaphene, DDT, and chlordane applied before 7 a.m. to 5.2 acres of alfalfa. in bloom, Logan, Utah, July-August 1950.

\begin{tabular}{|c|c|c|c|}
\hline INSECTICIDE & $\begin{array}{c}\text { Dosage } \\
\text { PER ACre }\end{array}$ & $\begin{array}{l}\text { Maximum } \\
\text { Population } \\
\text { Visiting } \\
\text { FlOWERS } \\
\text { ON DAY OF } \\
\text { TREATMENT }\end{array}$ & $\begin{array}{l}\text { Estimated } \\
\text { Kill of } \\
\text { Field } \\
\text { Folde }\end{array}$ \\
\hline Toxaphene & Pounds & Number & Per Cent \\
\hline Spray & 1.5 & 61296 & 0 \\
\hline $\begin{array}{l}\text { Dust } \\
\text { DDT }\end{array}$ & 1.7 & 33693 & 1 \\
\hline Spray & 0.5 & 25574 & 0 \\
\hline $\begin{array}{l}\text { Dust } \\
\text { Chlordane }\end{array}$ & 0.5 & 16643 & 10 \\
\hline Spray & 1.0 & $\begin{array}{l}37752 \\
38970\end{array}$ & $\begin{array}{r}19 \\
8\end{array}$ \\
\hline Dust & 1.0 & 33287 & 4 \\
\hline
\end{tabular}

0.5 pound per acre, and results with chlordane were again variable. The three tests with chlordane in this series bring to eight the number of satisfactory tests made at a dosage of 1 to 1.25 pounds per acre. Of these tests, only one with dust and one with spray gave a kill exceeding 10 per cent. Variability has been a characteristic of results with chlordane, and this insecticide has tended to be the exception to the rule that dusts are more toxic than sprays.

In 1952 we turned our attention to more recently developed insecticides that growers were likely to use. Aldrin, heptachlor, malathion, and TEPP were tested at the most generally useful dosages (Table 2). When applied in the early morning, all these insecticides gave 10per cent mortality or higher. The high kill obtained with 6 ounces of TEPP was rather surprising, although we had assumed earlier that this insecticide would have to be applied in the evening if dam-

Table 2.-Mortality of honey bees caused by various insecticide sprays applied to 4.3 acres of alfalfa in bloom, Logan, Utah, August 1952.

\begin{tabular}{|c|c|c|c|}
\hline INSECTICIDE & $\begin{array}{c}\text { Dosage } \\
\text { PER } \\
\text { ACrE }\end{array}$ & $\begin{array}{l}\text { Maximum } \\
\text { Population } \\
\text { Visiting } \\
\text { Flowers, } \\
\text { Day of } \\
\text { TreatMent }\end{array}$ & $\begin{array}{c}\text { Estruated } \\
\text { KILL OF } \\
\text { FIELD } \\
\text { ForCE }\end{array}$ \\
\hline $\begin{array}{l}\text { Morning applications: } \\
\text { Aldrin } \\
\text { Heptachlor } \\
\text { Malathion } \\
\text { TEPP } \\
\text { Evening application: } \\
\text { TEPP }\end{array}$ & $\begin{array}{l}\text { Ounces } \\
\qquad \begin{array}{c}2 \\
4 \\
10 \\
6 \\
6\end{array}\end{array}$ & $\begin{array}{c}\text { Number } \\
\\
17746 \\
49235 \\
29734 \\
14900 \\
\\
31468\end{array}$ & $\begin{array}{c}\text { Per Cent } \\
10 \\
26 \\
46 \\
63 \\
\end{array}$ \\
\hline
\end{tabular}

age to bees were to be minimized. A evening application was included to verif the assumption that it would be relativel harmless by the beginning of the fligh period the next day. Even then the kil was 6 per cent of the maximum visitin population. At least part of this kill wa the result of directly spraying late-forag ing bees and does not necessarily indicato that the TEPP was still capable of killing bees 12 or more hours after application Although the mortality from any ap plication of insecticide occurred largely within the first 24 hours and usually was nearly complete within 48 hours, the lethal effect of a few insecticides continued for a longer time. This was the case with dieldrin applied at 0.56 pound per acre in 1949; bees died for a week or more In 1952 malathion gave a prolonged kill. Poisoned freshly killed bees were still re covered in small numbers after 4 days, when counts were discontinued. The 46 per cent mortality reported for malathion is therefore approximate but incomplete.

Table 3.-Mortality of honey bees caused by various insecticide sprays applied before 7 a.m. to 4.8 acres of alfalfa in bloom, Logan, Utah, August 1953.

\begin{tabular}{|c|c|c|c|}
\hline INSECTICIDE & $\begin{array}{c}\text { Dosage } \\
\text { PER } \\
\text { ACRE }\end{array}$ & $\begin{array}{c}\text { Maximum } \\
\text { Population } \\
\text { Visiting } \\
\text { Flowers } \\
\text { ON Day of } \\
\text { Treatment }\end{array}$ & $\begin{array}{l}\text { EstI- } \\
\text { MATED } \\
\text { KILL OF } \\
\text { FIELD } \\
\text { FORCE }\end{array}$ \\
\hline $\begin{array}{l}\text { Systox } \\
\text { Endrin } \\
\text { Aldrin } \\
\text { Dieldrin }\end{array}$ & $\begin{array}{c}\text { Ounces } \\
6 \\
4 \\
2 \\
1\end{array}$ & $\begin{array}{c}\text { Number } \\
22535 \\
39727 \\
72019 \\
128008\end{array}$ & $\begin{array}{c}P e r \text { Cent } \\
1 \\
13 \\
22 \\
36\end{array}$ \\
\hline
\end{tabular}

In 1953 we tested Systox and endrin at dosages promising for control use, retested aldrin at $\mathcal{2}$ ounces per acre, and tried $a$ much lower dosage of dieldrin than was used in 1949. Results of these tests are given in table 3. Only Systox gave a favorable result, killing but 1 per cent of the bees. Endrin, killing 13 per cent, probably deserves further testing as a bloom-period treatment, perhaps at a slightly lower dosage or as an evening application. The high kills with aldrin and dieldrin at low dosages rule them out as possible bloom-period treatments. The estimate for 1 ounce of dieldrin is probably minimum, since the field kill used was based on only the first 2 days of a 5 -day 
Table 4.-Mortality of honey bees occurring at the hives and in the treated acreage when various insecticides were applied to alfalfa in various Logan, Utah, 1950-53.

\begin{tabular}{|c|c|c|c|c|}
\hline \multirow[b]{2}{*}{ INSECTICIDE ${ }^{1}$} & \multirow{2}{*}{$\begin{array}{c}\text { Dosage } \\
\text { PER } \\
\text { ACRE }\end{array}$} & \multicolumn{2}{|c|}{$\begin{array}{c}\text { BeEs Dring as } \\
\text { Result of } \\
\text { TreatMent }\end{array}$} & \multirow{2}{*}{$\begin{array}{l}\text { KILL } \\
\text { OCCURRING } \\
\text { IN THE } \\
\text { FIELD }\end{array}$} \\
\hline & & At hives & In field & \\
\hline $\begin{array}{l}\text { Toxaphene } \\
\text { TEPP (P.M.) } \\
\text { Aldrin } \\
\text { Heptachlor } \\
\text { TEPP } \\
\text { Dieldrin } \\
\text { Malathion } \\
\text { DDT }\end{array}$ & $\begin{array}{l}\text { Pounds } \\
1.5 \\
0.38 \\
0.13 \\
0.25 \\
0.38 \\
0.06 \\
0.63 \\
0.5\end{array}$ & $\begin{array}{c}\text { Number } \\
25 \\
1652 \\
1374 \\
7861 \\
3745 \\
10384 \\
317 \\
0\end{array}$ & $\begin{array}{r}\text { Number } \\
0 \\
309 \\
464 \\
4784 \\
5709 \\
35313 \\
10081 \\
1649\end{array}$ & $\begin{array}{c}\text { Per Cent } \\
0 \\
16 \\
25 \\
38 \\
60 \\
77 \\
97 \\
100\end{array}$ \\
\hline
\end{tabular}

1 Except as noted, the applications were made before 7 A.M. DDT was applied as a dust; all other insecticides were used as sprays.

period of kill.

Early in these studies it appeared that the relative toxicity of insecticide treatments to honey bees could be reasonably well established by merely making daily counts of dead bees at the hives, provided the apiary was adjacent to the field so that most of the poisoned bees able to leave the field would reach the hives before becoming incapacitated. Furthermore many beekeepers and growers have the impression that a treatment has not harmed the apiary if dead bees have not accumulated in large numbers at the hives. Table 4 shows that there is little relation between the number of bees dying at the hives and the total kill. Therefore, field counts must be made to evaluate the toxicity to bees of a field application of an insecticide.

Throughout our studies we have noticed that most of the insecticides caused many bees to leave the field after initial contact for at least a few hours. This has been attributed to repellency, although it is recognized that poisoning by a sublethal dosage might cause affected bees to return to the hive until they have recovered. In $1953,1.5$ acres of seed alfalfa adjacent to the test field provided a reasonably good place to establish check stations to aid in the study of repellency on the treated acreage. The counts made in treated and check areas are presented in table 5 . The check stations were not established until after the endrin had been applied.

A sharp decline in the visiting population occurred by afternoon on the days when endrin, aldrin, and dieldrin were applied. On the morning Systox was applied, the temperature did not fall below $70^{\circ} \mathrm{F}$. and a small population was already in the field at 6. A.M. These visiting bees were hit by the Systox spray, and most of them left the field immediately. The population remained low all day, indicating that many potential visitors stayed away from the field in the morning as well as the afternoon. In all cases mortality accounted for only a small fraction of the population decline.

Repellency persisted until the afternoon of the day following spraying except when endrin was applied, when there was a temporary interruption in the morning of the second day. This insecticide was applied at the beginning of the flowering period when the amount of bloom was increasing rapidly and the flowers were most attractive. It is assumed that the field was un-

Table 5.-Repellency to honey bees of field applications of insecticides, Logan, Utah, 1953.

\begin{tabular}{|c|c|c|c|c|c|c|c|c|}
\hline \multirow{3}{*}{$\begin{array}{l}\text { Insecti- } \\
\text { CIDE }\end{array}$} & \multirow{2}{*}{\multicolumn{2}{|c|}{ Date (August) }} & \multirow{3}{*}{$\begin{array}{c}\text { Minimum } \\
\text { Temper- } \\
\text { Ature }\end{array}$} & \multicolumn{4}{|c|}{ Honex Bees Visiting Flowers on- } & \multirow{3}{*}{$\begin{array}{c}\text { DeCLINE } \\
\text { CAUSED } \\
\text { BY MoR- } \\
\text { TALITY }\end{array}$} \\
\hline & \multirow[b]{2}{*}{ Applied } & & & \multicolumn{2}{|c|}{ Treated Area } & \multicolumn{2}{|c|}{ Untreated Area } & \\
\hline & & $\begin{array}{c}\text { Bees } \\
\text { Counted }\end{array}$ & & A.M. & P.M. & A.M. & P.M. & \\
\hline \multirow{4}{*}{ Endrin } & \multirow{3}{*}{5} & & Degrees $F$. & \multicolumn{5}{|c|}{ Hundreds of Bees per Acre } \\
\hline & & 4 & 53 & 72 & 77 & - & - & - \\
\hline & & 5 & 48 & 83 & 21 & - & - & 8 \\
\hline & \multirow{3}{*}{12} & 6 & 48 & 119 & 66 & - & - & - \\
\hline \multirow[t]{2}{*}{ Dieldrin } & & 11 & 45 & 189 & 234 & 218 & 368 & - \\
\hline & & 12 & 46 & 267 & 28 & 315 & 252 & 64 \\
\hline \multirow{3}{*}{ Aldrin } & \multirow{3}{*}{19} & 13 & 47 & 46 & 211 & 155 & - & - \\
\hline & & 18 & 66 & 181 & 153 & 116 & 155 & - \\
\hline & & 19 & 55 & 150 & 60 & 136 & 174 & 20 \\
\hline \multirow{4}{*}{ Systox } & \multirow{4}{*}{26} & 20 & 53 & 56 & 140 & 111 & 150 & - \\
\hline & & 25 & 46 & 106 & 109 & 73 & 63 & - \\
\hline & & 26 & 70 & 40 & 47 & 53 & 82 & 0.5 \\
\hline & & 27 & 60 & 62 & 90 & 77 & 82 & - \\
\hline
\end{tabular}


usually inviting to the bees, and many visited the field only to be repelled again.

Discussion.-To control insect pests of forage seed crops during the flowering period, one should first choose prebloom treatments that are most likely to avoid the necessity of later applications when the plants are in flower. If bloom-stage treatments cannot be avoided, wise selection of the insecticide is in order. Insecticides that show little toxicity to honey bees regardless of dosage, such as toxaphene, should be utilized wherever possible. When a potentially damaging treatment is necessary, it should be applied under conditions favoring minimum kill and the dosage should be kept as low as possible.

We have arbitrarily set a mortality of 10 per cent as the limit for sanction of a bloom-stage application. Naturally there is ample room on both sides of this limit for the use of judgment in particular cases. An important factor is the amount of bloom within foraging range of affected colonies that is treated at one time. Treatments interpreted as a little too toxic under our test conditions may not be prohibitive when there is ample untreated acreage in the vicinity.

In the initial report on these studies Todd et al. (1949) pointed out that the full seriousness to the beekeeper of treating fields in bloom may lie not in the percentage of bees killed but rather in the timing of the treatment in relation to the nectar flow. We are now even more convinced that this is true. A high kill of the field force sometimes does not appear to hurt a colony substantially, but the loss of the foraging population for a short period during a heavy nectar flow usually spells the difference between a good and a poor honey crop for the beekeeper.

Finally, it should be emphasized that the tests reported here do not shed much light on the damage to native species of bees serving as pollinators. One test, Bohart \& Lieberman (1949), with 0.6 pound of DDT applied as a 3-per cent dust gave about 15-per cent mortality to a nesting aggregation of alkali bees, but the following year the population appeared to be normal. In another, unreported test under the same conditions an application of 2.3 pounds of toxaphene dust gave a comparable mortality. The danger of applying "across the board" the results of tests on one kind of bee was emphasized when a large cage that had been dusted with toxaphene and found safe to use with bumble bees was later used for a colony of Melipona with disastrous results.

SuMmary.-In 1950, 1952, and 1953 tests were conducted to learn the effect of field applications of insecticides on honey bees. From 4.3 to 5.2 acres of seed alfalfa in bloom near Logan, Utah, were sprayed or dusted before 7 A.M. or after 7 P.M. The effect of each application on the field force of a small apiary placed at the edge of the field was measured by counting the dead bees at the hives and in the treated acreage.

In each test the dosage was one considered useful for controlling harmful insects on alfalfa in bloom. On the basis of 10 per cent mortality being the limit for sanction, the following treatments are considered as too toxic to honeybees: early morning sprays of TEPP 6 ounces, malathion 10 ounces, dieldrin 1 ounce, heptachlor 4 ounces, aldrin 2 ounces, chlordane 1 pound, and endrin 4 ounces, and an early morning dust of DDT 0.5 pound per acre. Treatments in addition to toxaphene classified as safe include morning sprays of DDT 0.5 pound and Systox 6 ounces, and an evening spray of TEPP 6 ounces per acre.

There was no relation between the number of bees dying at the hives and the number dying in the field. Most of the insecticides tested caused many bees to stay away from the field for at least a few hours following initial contact. Results of tests with honey bees do not necessarily apply to native bees.

\section{Literature Cited}

Bohart, George E., and F. V. Lieberman. 1949. Effect of an experimental field application of DDT dust on Nomia melanderi. Jour. Econ. Ent. 42(3): 519-22.

Knowlton, G. F., W. P. Nye, F. V. Lieberman, F. E. Todd, and G. E. Bohart. 1950. New insecticides: What is their effect on bees when applied to flowering alfalfa? Utah. Agr. Expt. Sta. Farm and Home Sci. 11(1): 1, 17-9.

Todd, F. E., F. V. Lieberman, W. P. Nye, and G. F. Knowlton. 1949. The effect of field applications of insecticides on honey bees. Agr. Chem. 4(8): 27-9, 77 . 